\title{
High-yield production and biochemical characterization of a-galactosidase produced from locally isolated Penicillium sp.
}

\author{
Naganagouda Kote ${ }^{1}$, A. C. Manjula2* T. Vishwanatha ${ }^{3}$ and Aravind Gouda G. Patil ${ }^{4}$
}

\begin{abstract}
Background: a-Galactosidase is widely used in various biotechnological applications such as food processing, beet sugar, the pulp and paper industries, synthesis of oligosaccharides by trans-galactosylation, hydraulic fracturing of oil and gas wells, and medical applications.

Results: Screening and identification of fungi for a-galactosidase activity was performed. The isolate Penicillium sp. showed good a-galactosidase activity. a-Galactosidase production by the fungal strain Penicillium sp. cultivated in solid state fermentation (SSF) conditions using copra mannan extract as nutrient medium was investigated. The maximum a-galactosidase activity of $5.391 \mathrm{U} / \mathrm{mL}$ was obtained in defatted copra meal (dFCO) as carbon source, which is $2-3 \%$ greater as compared with commercial mannans and unprocessed copra meal. The highest product yield of a-galactosidase was obtained with media containing yeast extract $(6.672 \mathrm{U} / \mathrm{ml})$ as organic nitrogen and ammonium nitrate $(6.325 \mathrm{U} / \mathrm{ml})$ and as inorganic nitrogen source with media pH 5.5, and the time course of enzyme production was at the 5 th day of fermentation, respectively. The optimum $\mathrm{pH}$ of a-galactosidase was obtained at pH 5 and optimum temperature at $60^{\circ} \mathrm{C}$. The enzyme was stable between pH 4 and 6 and retained more than $50 \%$ of residual activity for an $8-\mathrm{h}$ incubation period. The $\mathrm{Ca}^{+2}$ ions enhanced the enzyme activity and $\mathrm{Mn}^{+2}$ ions have not altered the enzyme activity, whereas $\mathrm{Hg}^{+2}$ strongly inhibited the enzyme activity.
\end{abstract}

Conclusions: The findings of present investigations on a-galactosidase are of particular interest for its application in the food processing industry.

Keywords: a-Galactosidase, Penicillium sp., Copra meal, Food processing

\section{Background}

The enzymes responsible for hydrolyzing galactosidic linkages are termed as galactosidases. There are two types of galactosidases, viz., $\alpha$-galactosidases and $\beta$-galactosidases depending on the configuration of the anomeric carbon atom of galactose in the substrate molecule on which they act. The $\alpha$-galactosidases $(\alpha$-D-galactosidegalactohydrolase, EC 3.2.1.22) are carbohydrases that catalyze the hydrolysis of $\alpha$-galactosidic linkages in galacto-oligosaccharides such as raffinose, melibiose, stachyose, verbascose and ajugose,

\footnotetext{
*Correspondence: dracmanjulam3@gmail.com

2Department of Sericulture, Maharani's Science College for Women, Palace Road, Bengaluru, Karnataka 560001, India

Full list of author information is available at the end of the article
}

polysaccharide-like galactomannans, and glycoconjugates such as glycoproteins and glycolipids. For ceramidetrihexo-saccharides, their higher homologous and derivatives are also cleaved by the action of $\alpha$-galactosidase (Katrolia et al. 2014; Dey and Pridham 1972.).

$\alpha$-Galactosidases have widely used in both biotechnological and medical applications. For instance, $\alpha$ galactosidases offer a promising solution for the degradation of raffinose family oliogo-saccharides (RFOs) present in soy beans and other leguminous food and feed that cause intestinal discomfort, flatulence, and low feed utilization in monogastritc animals (Naganagouda and Mulimani 2006; Naganagouda et al. 2007). In beet sugar industry, $\alpha$-galactosidases are used to remove 
raffinose from beet molasses increasing the sucrose yield (Shibuya et al. 1997). $\alpha$-Galactosidase is also used to improve the gelling properties of galactomannans to be used as food thickeners (Chen and Mustapha 2012). The enzymic conversion of RFOs in soymilk may be a rational alternative to improve the nutritional quality of this lowcost, high-quality protein supplement for humans and animals (Farzadi et al. 2011). In the pulp and paper industry, $\alpha$-galactosidase could enhance the bleaching effect of $\beta$ mannanases on softwood pulp (Clarke et al. 2000). Furthermore, these enzymes are used for the treatment of Fabry's disease (Kang et al. 2019), in xenotransplantation (Liu et al. 2007) and in blood group transformation for safety transfusion (Balabanova et al. 2010).

$\alpha$-Galactosidases are widely distributed in nature among plants, animals, and microorganisms. Due to high expression levels, extracellular secretion, ease of cultivation, and scope for improvement of yield by optimization of culture conditions, several microorganisms have been exploited for the production of $\alpha$-galactosidase for use in various biotechnological and medical applications. $\alpha$-Galactosidase from bacteria, especially probiotic bacteria like bifido and lactic acid bacteria are used as "live cultures" in fermented soymilk for removal of RFOs or in the production of $\alpha$ galactosidases (Farzadi et al. 2011; Scalabrini et al. 1998).

The huge amounts of low-cost byproducts are generated by agro-industrial activities and these are susceptible to be transformed in culture media for the production of highvalue-added bio-products such as ethanol and other biofuels, enzymes, and heterologous proteins (Álvarez-Cao et al. 2018; Álvarez-Cao et al. 2019).

Among filamentous fungi, in literature, the distribution of $\alpha$-galactosidase in fungi, with generally regarded as safe (GRAS) status, such as Aspergillus and Saccharomyces sp. have been reported for the production of $\alpha$ galactosidases because they can be cultivated on cheap agricultural residues and usually secrete high levels of enzyme into the culture media, which contribute a great deal in reducing the cost of enzyme production (Shankar and Mulimani 2007) and their application in commercial use in the food and feed industries.

The cost of the enzyme actually limits the profitability of most of the above cited applications. The use of cheap sub-products, such as molasses and whey, as substrates for production of Saccharomyces cerevisiae $\alpha$ galactosidase (ScAGal) was previously reported and might favor the economy of the processes (Âlvarez-Cao et al. 2018). The use of residues as culture media to produce the required enzymes can help with the economy of the process. Copra mannan is a sub-product of coconut industry after coconut oil extraction, rich in manno and galacto-oligosaccharieds.

The aim of the present study is to evaluate the production of $\alpha$-galactosidase from the locally isolated fungal cultures. Further, there are very few reports using copra mannan as a source for the production of $\alpha$ galactosidase. Therefore, the present investigation was carried out for the production of $\alpha$-galactosidase from selected fungal strain under solid state fermentation. Further, the enzyme was studied with the biochemical characterization.

\section{Methods \\ Chemicals}

Locust bean gum (LBG) and guar gum were obtained from Sigma, USA. All other reagents used were of analytical grade. All solutions were prepared in doubledistilled water obtained from a distilled water plant (Distillon 4 S).

\section{Preparation of buffers}

Buffers were prepared according to Gomori (1946). All the preparations were carried out using double-distilled water and $0.5 \mathrm{M}$ solution of potassium hydrogen phthalate was used to standardize $\mathrm{pH}$ meter.

\section{Preliminary screening and identification of fungi}

Different soil samples collected locally from garden and composts were used in the present study to isolate galactosidases producing fungi. The fungal strains were isolated from soil samples using dilution-plating technique. One gram of garden and compost samples was mixed in $9 \mathrm{ml}$ distilled water. This suspension was serially diluted to $10^{-4}$. One milliliter of the diluted samples from $10^{-3}$ to $10^{-4}$ dilutions was plated on sterile copra meal agar plate (Copra meal, $1 \mathrm{~g}$; agar, $15 \mathrm{~g}$; $\mathrm{NaNO}_{3}, 1 \mathrm{~g} ; \mathrm{K}_{2} \mathrm{HPO}_{4}$, $1 \mathrm{~g} ; \mathrm{MgSO}_{4} \cdot 7 \mathrm{H}_{2} \mathrm{O}, 0.5 \mathrm{~g}$; yeast extract, $1 \mathrm{~g}$ in $1000 \mathrm{ml}$ distilled water and to eliminate the bacterial contamination, $0.080 \mathrm{~g}$ or $0.008 \%$ streptomycin was added to one of the medium) surface and incubated at $37{ }^{\circ} \mathrm{C}$ for $3-4$ days. Microscopic observation was performed to determine the morphological characteristics of the fungal isolates.

\section{Secondary screening}

Those isolated organisms from the preliminary screening were cultured in liquid media containing $2 \%$ locust bean gum, $0.1 \% \mathrm{~K}_{2} \mathrm{HPO}_{4}$, and $0.05 \% \mathrm{MgSO}_{4} \cdot 7 \mathrm{H}_{2} \mathrm{O}$ at $\mathrm{pH} 5.5$ in an Erlenmeyer flasks. After incubation on a rotary shaker $\left(37^{\circ} \mathrm{C}, 180 \mathrm{rpm}\right)$ for 7 days, the culture broth was centrifuged (12085.2 $\times g$ for $20 \mathrm{~min}$ ) and the supernatant was collected for enzyme assay. Among 3 isolates tested, one isolate was found to be a potent galactosidase producer and were designated as Penicillium sp. The strains were maintained on potato dextrose agar and used for further study on $\alpha$-galactosidase production. 
Maintenance and propagation of fungal cultures

The fungal cultures were maintained and propagated on potato dextrose agar (PDA) medium.

\section{Enzyme production} Inoculum preparation

The spore suspension was prepared by adding sterilized distilled water containing $0.01 \%$ Tween- 80 and scrapping the spores of Penicillium sp. from 7-day grown slants.

\section{Medium}

The following medium was used. The composition of medium (g/liter) was as follows:

$\mathrm{K}_{2} \mathrm{HPO}_{4}, 3 \mathrm{~g}$

$\mathrm{MgSO}_{4} \cdot 7 \mathrm{H}_{2} \mathrm{O}, 0.5 \mathrm{~g}$

Yeast extract, $5 \mathrm{~g}$

Guar gum, $20 \mathrm{~g}$

The $\mathrm{pH}$ of the medium was adjusted to 5.5 .

\section{Submerged fermentation}

Different carbon sources like commercial mannans (LBG and guar gum), simple sugars (glucose, sucrose, lactose, galactose, mannose and xylose), copra meal, and defatted copra meal were used as potential inducers of the enzyme activities in Penicillium sp. For batch culture, 50 $\mathrm{ml}$ of basal medium was taken in a 250-ml Erlenmeyer flask and sterilized. After autoclaving, the flasks were inoculated with spores $\left(2 \times 10^{6}\right)$ of Penicillium sp. The flasks were incubated at $37^{\circ} \mathrm{C}$ for 5 days on an orbital shaker at $120 \mathrm{rpm}$. The mycelium was removed from culture broth by filtration through muslin cloth followed by Whatman No. 1 filter paper and the clear supernatant phase was used as crude $\alpha$-galactosidase.

\section{Enzyme assay}

$\alpha$-Galactosidase activity was carried out according to method of Dey and Pridham (1972). One milliliter of reaction mixture contains $100 \mu \mathrm{l}$ of suitably diluted enzyme with $50 \mu \mathrm{l}$ of $10 \mathrm{mM}$ chromogenic substrate (pnitrophenyl $\alpha$-D-galactopyranoside, PNPG) and $850 \mu \mathrm{l}$ of $0.2 \mathrm{mM}$ phosphate buffer $\mathrm{pH}(7.5)$ at $50^{\circ} \mathrm{C}$ for $10 \mathrm{~min}$. The reaction was terminated by adding $2 \mathrm{ml}$ of $0.2 \mathrm{M}$ sodium carbonate solution. The amount of p-nitrophenol released was estimated from absorbance at $405 \mathrm{~nm}$. Enzyme activity was expressed as the amount of enzyme required to liberate $1 \mu \mathrm{mol}$ of product per minute under the assay conditions.

\section{Defatting methods of copra}

In order to remove the oil content from the copra, the treatment of copra was carried out according to the methods of Lin and Chen (2004). The copra was finely ground with a grinder for $5 \mathrm{~min}$ and sieved (30 mesh); the powder was designated as $\mathrm{CO}$. $\mathrm{CO}$ was boiled for $2 \mathrm{~h}$ with two volumes of distilled water. The cooled CO suspension was then placed at $4{ }^{\circ} \mathrm{C}$ overnight to allow the oil to solidify and finally be removed. The dried and sieved residues were designated as FCO. FCO was then defatted by the solvent extraction using n-hexane for 24 h. One liter of solvent $\mathrm{n}$-hexane was mixed with $100 \mathrm{~g}$ of ground copra in a beaker and left overnight. The copra suspension was then filtered through Whatman No. 1 filter paper. The product was designated as $\mathrm{dFCO}$, after the residues were oven-dried and sieved. All samples were kept in a desiccator until used.

\section{Biochemical characterization of a-galactosidase Optimum $\mathrm{pH}$}

In order to determine optimum $\mathrm{pH}, 100 \mu \mathrm{l}$ of suitably diluted (in $0.2 \mathrm{M}$ acetate buffer of $\mathrm{pH} 5$ ) enzyme was incubated with $900 \mu \mathrm{l}$ LBG substrate prepared in different buffers ranging from $\mathrm{pH} 3.0$ to 9.0 for $20 \mathrm{~min}$ at $50^{\circ} \mathrm{C}$. The following range of buffers was used: $\mathrm{pH} 3.0-5.6$ (acetate), pH 5.8-7.2 (citrate-phosphate), and $\mathrm{pH} 7.2-9.0$ (tris- $\mathrm{HCl}$ buffer). The initial $\mathrm{pH}$ of the fermentation medium was set to $3.5,4.0,5.0,5.5,6.0,6.5,7.0,7.5$, and 8.0 before inoculation. The $\mathrm{pH}$ was monitored but not controlled during the course of fermentation.

\section{pH stability}

To determine the $\mathrm{pH}$ stability, the enzyme was incubated with substrate at the desired $\mathrm{pH}$ for $16 \mathrm{~h}$ at $4{ }^{\circ} \mathrm{C}$. Residual activity was calculated in each sample by $\alpha$-galactosidase against enzyme control sample at optimum $\mathrm{pH}$.

\section{Optimum temperature}

Optimum temperature was determined by incubating $100 \mu \mathrm{l}$ of suitably diluted enzyme and $900 \mu \mathrm{l}$ of $0.5 \%$ LBG (prepared in $0.2 \mathrm{M}$ acetate buffer pH 5.0) substrate for $20 \mathrm{~min}$ at different temperatures ranging from 30 to $80^{\circ} \mathrm{C}$.

\section{Thermostability}

For determination of thermal stability, the enzyme was pre-incubated with the substrate without any stabilizers at $60^{\circ} \mathrm{C}$. Residual activity in each sample was calculated by doing assay against enzyme control sample at $\mathrm{pH} 5.0$ and $60^{\circ} \mathrm{C}$.

\section{Effect of nitrogen source}

Effect of various inorganic, organic $(0.5 \%$ in the medium), and combined nitrogen sources $(0.25 \%$ each in the medium) for the production of alpha-galactosidase (using 2\% defatted copra meal, dFCO) was carried out. 


\section{Effect of metal ions}

The metal ions to be tested were added to the assay system $(5 \mathrm{mM})$ and the enzyme assay was carried out. The results are expressed as a percentage of control.

\section{Results}

Screening and identification of fungi for a-galactosidase activity

Totally three $\alpha$-galactosidase-producing fungal strains were identified in preliminary screening. Active $\alpha$ galactosidase-producing strains that formed colonies on the copra meal agar plate were selected for secondary screening. In the secondary screening, the liquid medium with locust bean gum (LBG) as sole carbon source was used for the isolation of potent $\alpha$ galactosidase-producing strains. In preliminary screening, a total of three isolates were obtained from soil sample. In secondary screening, out of three isolates, one of the isolate (Penicillium sp.) showed good $\alpha$-galactosidase activity and these strains were selected for detailed taxonomical and optimization studies.

\section{Optimization of culture parameters for the production of a-galactosidase from Penicillium}

Optimization of composition of culture media and optimization of culture parameters like $\mathrm{pH}$ of media and incubation period are important for obtaining high enzyme activity from Penicillium sp.

\section{Effect of carbon sources and enzyme induction studies}

Results of these $\alpha$-galactosidase activities are given in Table 1 and Fig. 1. It is evident that copra meal defatted ( $\mathrm{dFCO}$ ) was the best inducer of $\alpha$-galactosidase synthesis in Penicillium sp. The use of commercial mannan-like locust bean gum and guar gum as substrate is uneconomical for large-scale production of alphagalactosidase. In order to use locally available copra waste into value-added products like enzymes, in this study, defatted copra meal was used as potent inducer of $\alpha$-galactosidase production. Among commercial mannans used for induction of $\alpha$-galactosidase, 2\% LBG induced maximum production of $\alpha$-galactosidase (4.784 $\mathrm{U} /$ $\mathrm{ml})$, then $2 \%$ guar gum $(3.126 \mathrm{U} / \mathrm{ml})$. Copra meal without defatting will not support the fungal growth because of high oil content, which inhibited the mannanase production. Coconut oil separated the culture broth from contacting with air and amount of dissolved oxygen in the cultural broth decreased, which in turn affected the growth of the fungi. The simple sugars like glucose, sucrose, galactose and xylose will not induced the enzyme production. The monosugars could cause catabolite repression, as reported for Penicillium sp. Hence, induction of enzyme activity was not observed. The enhanced production of enzyme was observed in Penicillium sp.
Table 1 Effect of different carbon sources on production of agalactosidase

\begin{tabular}{ll}
\hline Carbon source $(\mathbf{2} \% \mathbf{w} / \mathbf{v})$ & $\begin{array}{l}\text { Maximum a-galactosidase } \\
\text { activity }(\mathbf{U} / \mathbf{m l}) \\
\text { Penicillium } \mathbf{~ s p .}\end{array}$ \\
\hline Commercial mannans & \\
Locust bean gum & $4.784 \pm 0.29$ \\
Guar gum & $3.126 \pm 0.21$ \\
Copra mannans & $1.471 \pm 0.09$ \\
Copra meal (CO) (unprocessed) & $5.391 \pm 1.30$ \\
Copra meal (dFCO) sxcv (defatted) & \\
Simple sugars & $0.001 \pm 0.00$ \\
Glucose & $0.004 \pm 0.00$ \\
Sucrose & $0.021 \pm 0.00$ \\
Lactose & $0.001 \pm 0.00$ \\
Galactose & $0.001 \pm 0.00$ \\
Mannose & $0.001 \pm 0.05$ \\
Xylose & \\
Results are the rep & \\
\hline
\end{tabular}

Results are the representative of average of three experiments in duplicate SE at $5 \%$ level

using $2 \%$ defatted copra meal as carbon source compared to LBG.

\section{Effect of nitrogen source}

The effect of various inorganic and organic nitrogen sources on alpha-galactosidase synthesis was also studied and the results are given in Table 2. From the above findings it is clear that the Penicillium sp. showed significant enzyme activity even in the absence of any organic and inorganic nitrogen sources. The highest product yield of $\alpha$-galactosidase was found to be $6.736 \mathrm{U} / \mathrm{ml}$.

\section{Effect of initial $\mathrm{pH}$ of medium on enzyme production}

Penicillium sp. grows well at acidic $\mathrm{pH}$ and produces $\alpha$ galactosidase having good activity between $\mathrm{pH} 5$ and 6 with enzyme showing high optimum temperature for its activity.

The aim of the present investigation was to study the effect of different ranges of $\mathrm{pH}$ on the production of $\alpha$ galactosidase by Penicillium sp.

\section{Time course of a-galactosidase production}

The time course of $\alpha$-galactosidase production was studied. The results presented in Fig. 2 showed that $\alpha$ galactosidase was maximally produced at the 5 th day of fermentation, in optimized and non-optimized medium. When the fungal cultures were cultivated on optimized media with defatted copra meal as carbon source, the peak in $\alpha$-galactosidase production on optimized media was on day 5 for the Penicillium sp. The measured 


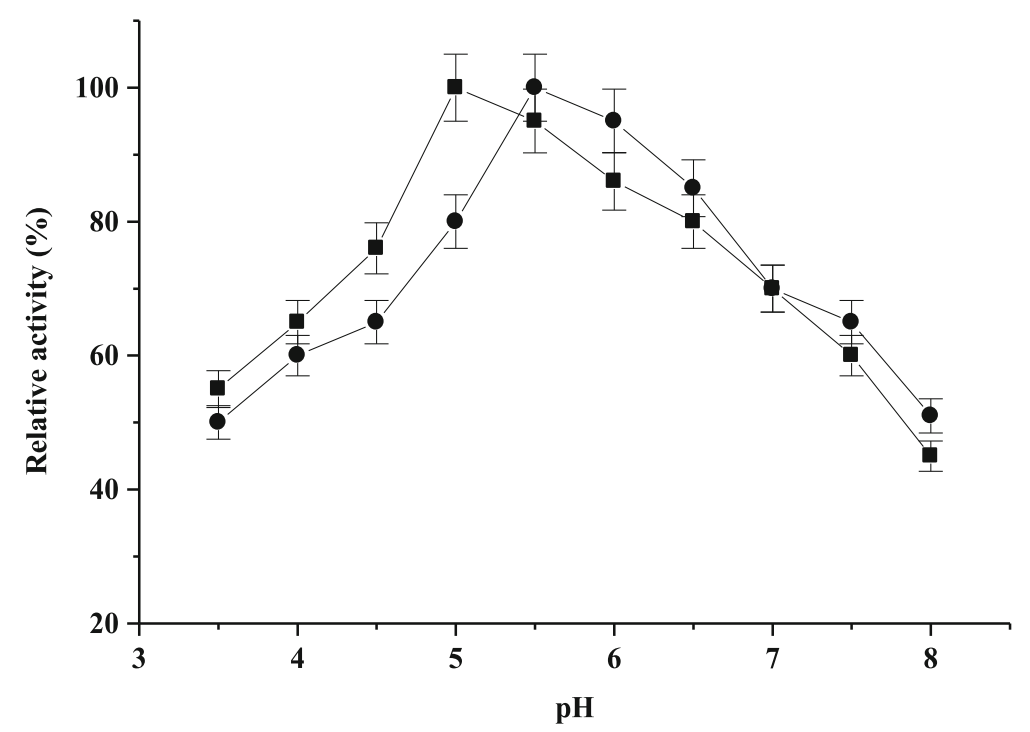

Fig. 1 Alpha-galactosidase production by Penicillium sp. (black square) at different initial pH

enzyme activities were $40.01 \mathrm{U} / \mathrm{ml}$ and $33.126 \mathrm{U} / \mathrm{ml}$, respectively. As pointed, $\alpha$-galactosidase activity was stable up to the 5th day and after which the enzyme activity fell possibly due to shift of $\mathrm{pH}$ and catabolic activity of the organism.

Table 2 Effect of various nitrogen sources on production of alpha-galactosidase (using 2\% defatted copra meal, dFCO)

\begin{tabular}{ll}
\hline $\begin{array}{l}\text { Nitrogen source } \mathbf{( 0 . 5 \%} \text { in the } \\
\text { medium) }\end{array}$ & $\begin{array}{l}\text { Maximum mannanase } \\
\text { activity }(\mathbf{U} / \mathbf{m l}) \\
\text { Penicillium } \mathbf{~ s p . ~}\end{array}$ \\
\hline $\begin{array}{l}\text { Inorganic nitrogen source } \\
\text { Ammonium sulfate }\end{array}$ & $5.729 \pm 1.39$ \\
Ammonium nitrate & $6.325 \pm 1.55$ \\
Sodium nitrate & $5.446 \pm 1.25$ \\
Potassium nitrate & $5.623 \pm 1.30$ \\
Ammonium acetate & $5.429 \pm 1.14$ \\
Urea & $5.463 \pm 1.30$ \\
Organic nitrogen source & \\
Yeast extract & $6.736 \pm 1.62$ \\
Beef extract & $5.821 \pm 1.30$ \\
Peptone & $5.916 \pm 1.47$ \\
Casein & $5.431 \pm 1.30$ \\
Soybean meal (defatted) & $5.402 \pm 0.99$ \\
Combined form* & \\
Yeast extract + ammonium nitrate & $6.672 \pm 2.00$ \\
Peptone + ammonium nitrate & $5.838 \pm 1.80$ \\
Casein + ammonium nitrate & $5.841 \pm 1.43$ \\
Soybean meal + ammonium nitrate & $5.624 \pm 1.30$ \\
\hline
\end{tabular}

Results are the representative of average of three experiments in duplicate SE at $5 \%$ level

\section{Characterization of a-galactosidase from isolated Penicillium sp. \\ Optimum $\mathrm{pH}$}

It is well established that the hydrogen ion concentration of enzymatic reaction mixture influences the rate of reaction with the substrate. The $\mathrm{pH}$ optimum was determined by using different buffers of $\mathrm{pH}$ ranging from 3.0 to 8.0. The $\mathrm{pH}$ activity profiles for the strain Penicillium sp. are shown in Fig. 3. From the figure, it is observed that the enzyme was considerably active from $\mathrm{pH} 3.5$ to 6.0 and maximum activity of $\alpha$-galactosidase was obtained at pH 5.0. The enzyme activity was gradually increased from 3.5 to 5.0. There was gradual decrease in enzyme activity after $\mathrm{pH}$ 5.0.

\section{pH stability}

The effect of $\mathrm{pH}$ on the stability of the enzyme is depicted in Fig. 4. The enzyme from Penicillium sp. was incubated in buffers of varying $\mathrm{pH}$ for $16 \mathrm{~h}$ at $4{ }^{\circ} \mathrm{C}$ and the residual activity was assayed. The enzyme was stable between $\mathrm{pH} 4.0$ and 7.0 and retained about $90 \%$ of its activity (Fig. 4).

\section{Effect of temperature}

Temperature is a critical variable in any enzymatic process, producing opposite effects by simultaneously increasing enzyme reactivity and inactivation rate. As a consequence, an optimum temperature will exist for any enzyme catalyzed process where those effects are optimally balanced. The temperature dependence of $\alpha$ galactosidase was determined by incubating the enzyme in $0.2 \mathrm{M}$ acetate buffer (pH 5.0). The effect of temperature on enzyme activity profile was shown in Fig. 5. It is clear that, the enzyme showed optimum 


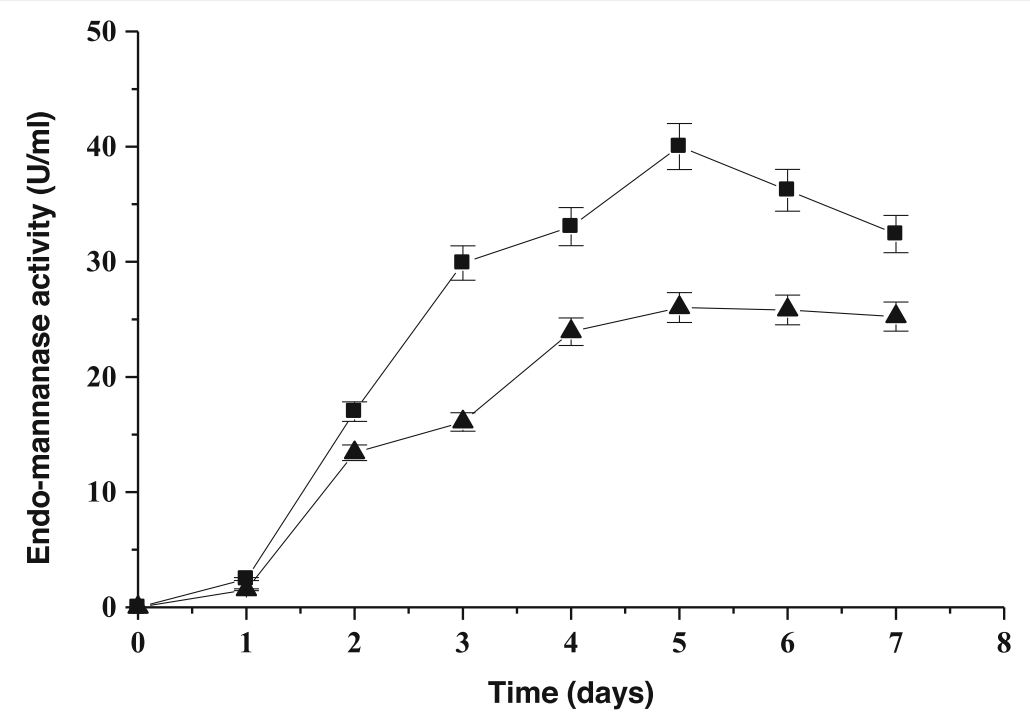

Fig. 2 Time course of endo- $\beta-1,4$ mannanase production by Penicillium sp. in SmF on defatted copra meal before and after optimization (black square indicates optimized and black triangle, non-optimized)

activity at $60^{\circ} \mathrm{C}$, whereas $\alpha$-galactosidase from the source Penicillium sp. exhibited its optimal activity at $65^{\circ} \mathrm{C}$.

\section{Thermal stability}

The effect of thermostability on $\alpha$-galactosidase produced from Penicillium sp. is displayed in Fig. 6. The enzyme was pre-incubated in $0.2 \mathrm{M}$ acetate buffer ( $\mathrm{pH} 5.5)$ at $60^{\circ} \mathrm{C}$ for different incubation time, i.e., $0 \mathrm{~h}$ to $12 \mathrm{~h}$ without any stabilizers. From the Fig. 6 it is noted that $\alpha$ galactosidase produced from the Penicillium sp. showed good thermal stability. The enzyme retained more than $50 \%$ of residual activity for $8 \mathrm{~h}$ incubation period.
$\alpha$-Galactosidase from Penicillium sp. exhibited thermo stability up to $60^{\circ} \mathrm{C}$, which appears to be a characteristic shared by other bacterial $\alpha$-galactosidase.

\section{Effect of metal ions}

Table 3 shows the effect of metal ions on $\alpha$ galactosidase activity. It is clear that $\alpha$-galactosidase from the source was strongly inhibited by $\mathrm{Hg}^{+2}$. Inhibition by mercuric ions suggested that the enzyme contains an essential sulfhydryl group. Significant inhibitory effect was also observed in the presence of $\mathrm{Ag}^{+}, \mathrm{Zn}^{+2} \cdot \mathrm{Ca}^{+2}$ enhanced the $\alpha$-galactosidase activity in the strain.

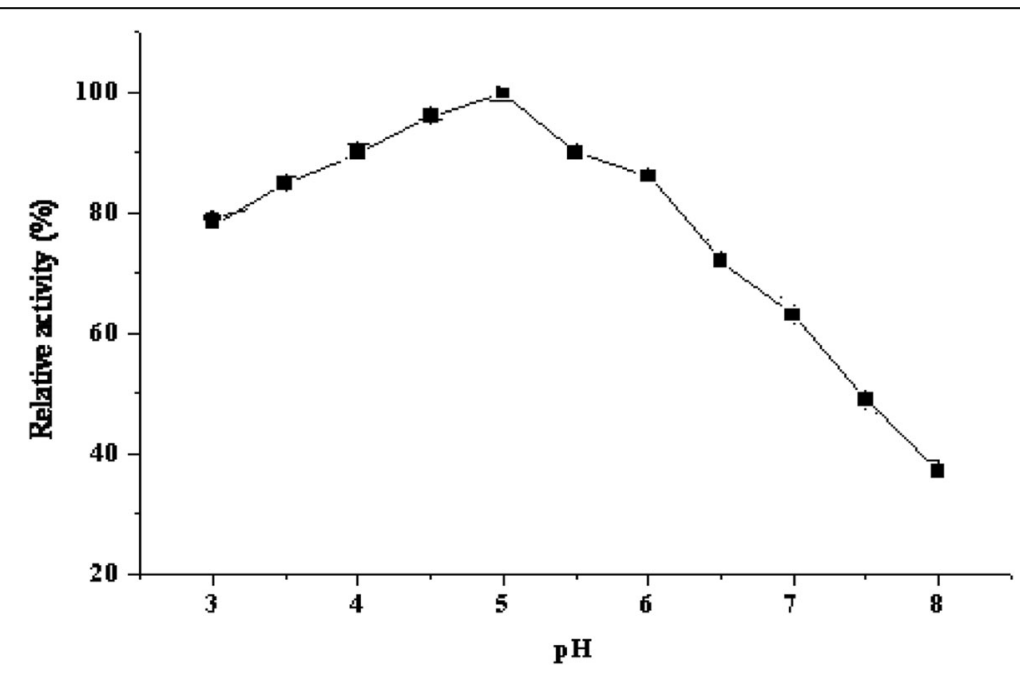

Fig. 3 Effect of pH on alpha-galactosidase activity in Penicillium sp. 


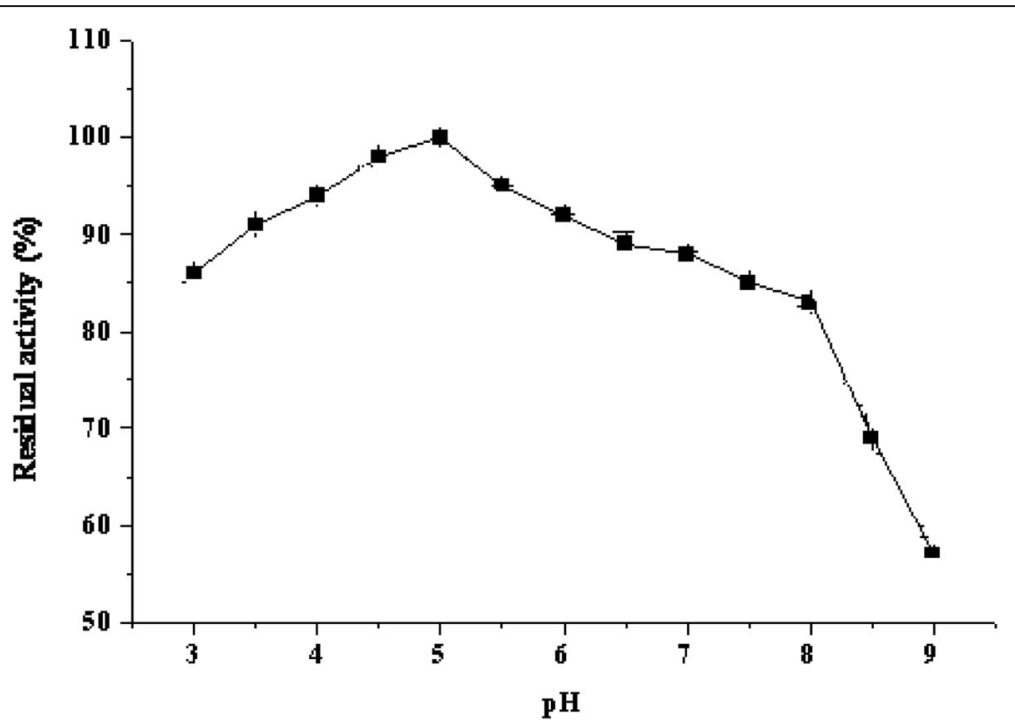

Fig. 4 pH stability of alpha-galactosidase in Penicillium sp.

\section{Discussion}

A screening method for detection of $\alpha$-galactosidaseproducing microorganism had been studied. Similar to ours, findings by Youssef et al. (2006), Hossain et al. (1996), and Lin and Chen (2004) have isolated the Aspergillus fungal cultures for $\beta$-mannanase activity using copra meal as a carbon source for cultivation. The biotechnological applications of $\alpha$-galactosidase includes the removal of raffinose family oligosaccharides (RFOs) in soymilk, beet sugar industry, flatulence, blood group conversion, etc. (Raja et al. 2020; Bhatia et al. 2019).

Carbon occupies a unique position among the essential elements required by microorganisms. When it is consumed, it undergoes three metabolic changes, viz., conversion into cell substances, carbon dioxide and accumulation in several metabolic products. Based on the type and nature of carbon source in the medium, the organism tries to grow and thus produces number of enzymes.

Similarly, Lin and Chen (2004) have made observation that fourfold enhanced production of mannanase by growing $A$. niger in medium containing $2 \%$ defatted copra meal. Therefore, based upon the same amount of carbon sources, the defatted copra carried the higher mannan content, which would induce more enzyme production by the microorganisms. Copra waste was apparently a better substrate because of its high reducing sugar content. Defatted copra also contained more protein and minor elements, which were more beneficial to fungal growth than other carbon sources. The medium must be designed to provide the essential elements

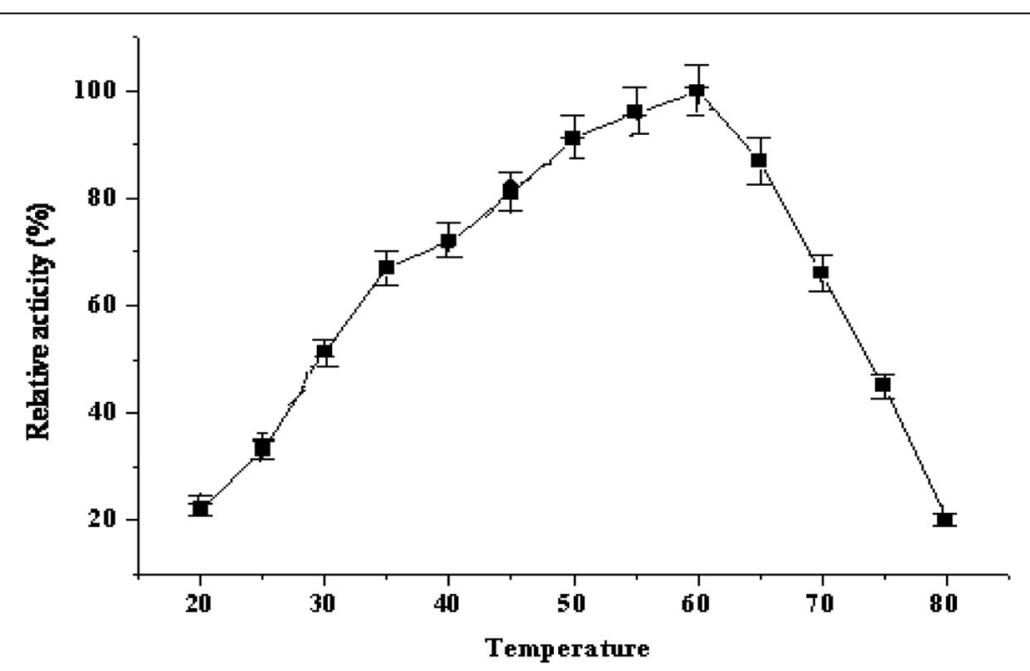

Fig. 5 Effect of temperature on the production of alpha-galactosidase in Penicillium sp. 


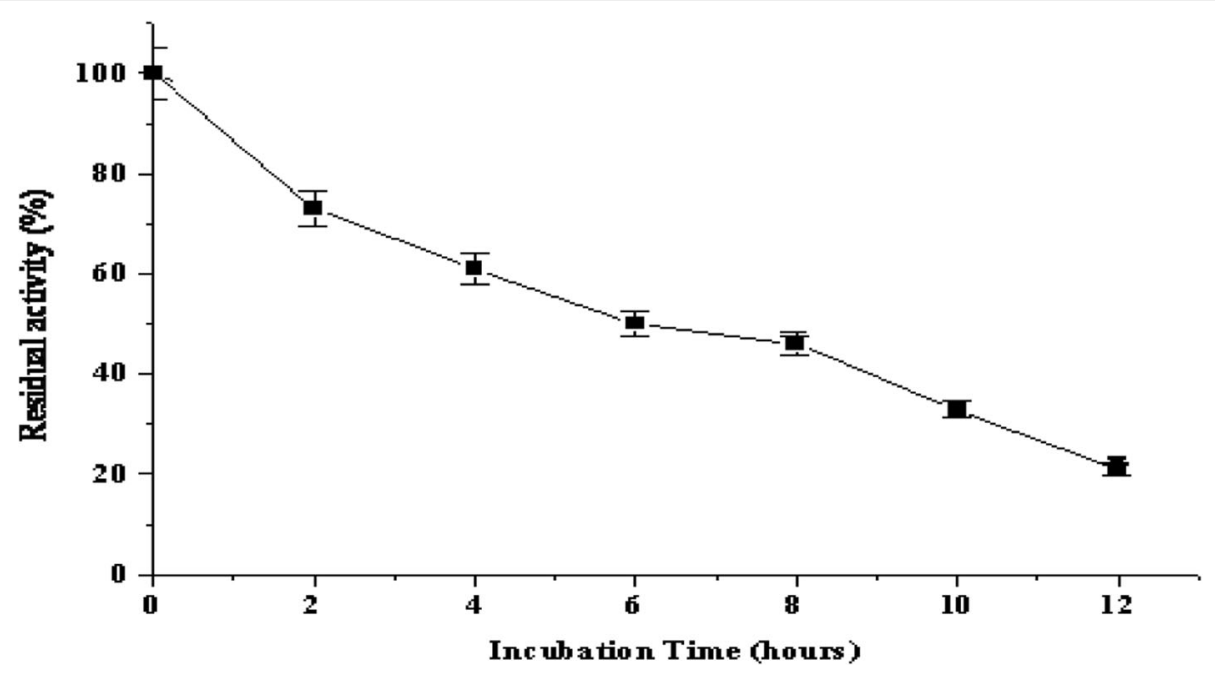

Fig. 6 Thermo stability of alpha-galactosidase from Penicillium sp.

carbon, nitrogen, sulfur, oxygen, phosphorous, magnesium, calcium, and numerous other trace elements such as iron, copper, cobalt, zinc, manganese, and molybdenum, which may be required to support active culture function. However, it is highly important in formulating an effective medium for use in a competitive enzyme production process to produce one which is both cheap and where possible, reproducible over a long production period. These relate to the phenomenon of induction, catabolite repression, and end product inhibition and in case of extracellular enzymes and protein release mechanisms.

Similar to our findings, Anisha (2017) have reported highest $\alpha$-galactosidase obtained in submerged fermentation on various carbon sources.

The mechanisms that govern the formation of extra cellular enzymes are influenced by the availability of precursors for protein synthesis. Furthermore, the nitrogen source can significantly affect the $\mathrm{pH}$ of the medium during the course of fermentation (Lin and Chen 2004).

Table 3 Effect of metal ions on a-galactosidase activity

\begin{tabular}{ll}
\hline $\begin{array}{l}\text { Metal } \\
\text { ion }(\mathbf{1} \\
\mathbf{m M})\end{array}$ & $\begin{array}{l}\text { \% Relative activity } \\
\text { Penicillium sp. }\end{array}$ \\
\hline $\mathrm{Ag}^{+2}$ & $13 \pm 1.30$ \\
$\mathrm{Hg}^{+2}$ & $11 \pm 1.10$ \\
$\mathrm{Zn}^{+2}$ & $15 \pm 1.50$ \\
$\mathrm{Mn}^{+2}$ & $100 \pm 10.00$ \\
$\mathrm{Co}^{+2}$ & $55 \pm 5.50$ \\
$\mathrm{Ca}^{+2}$ & $120 \pm 12.00$ \\
$\mathrm{~Pb}^{+2}$ & $43 \pm 4.30$ \\
$\mathrm{Mg}^{+2}$ & $31 \pm 3.10$ \\
\hline
\end{tabular}

Results are the representative of average of three experiments in duplicate SE at $5 \%$ level
Nitrogen is the principal element governing cell formation and synthesis of various constituents. It influences the synthesis of various enzymes especially in microorganisms, which are either accumulated inside the cell or excreted into the culture medium. The type of nitrogen and also its concentration influences markedly the yield and the rate of enzyme production.

These results are in concordance with the data of many investigators, who have reported that fungi produce more enzymes on addition of complex organic nitrogen sources (Anisha 2017; Naganagouda et al. 2009). Concerning the inorganic nitrogen sources used as shown in Table 2, a maximum activity was observed with ammonium nitrate in the Penicillium sp. $(6.325 \mathrm{U} /$ $\mathrm{ml})$. In case of organic nitrogen sources, a maximum activity was observed with yeast extract rather than peptone, beef extract, casein, and soybean meal (Table 2), respectively. In addition yeast extract showed a maximum production comparable with different inorganic nitrogen sources.

Among several cultural parameters influencing the product formation by microorganisms, the hydrogen concentration of the culture medium is considered extremely important. The higher concentration of hydrogen or hydroxyl ions exhibits the growth of microbial culture and thereby influence the yield of enzyme or metabolite production. There are distinct three types of microorganisms according to their tolerance of hydrogen and hydroxyl ions. These are acidophilic, alkalophilic, and mesophillic strains which grow at varying ranges of $\mathrm{pH}$ in the cultivation medium.

The influence of age of the culture is very important in influencing the growth as well as product formation either extracellular or intracellular under shake or stationary conditions of fermentation. 
Denaturation of enzyme possibly due to prolonged incubation could be the reason. Lin and Chen (2004) have compared time course of $\beta$-mannanase production by Aspergillus niger in shake cultures. They further reported that in shake culture $2^{\text {nd }}$ day maximum activity was obtained.

$\alpha$-Galactosidase produced by the genus Penicillium sp. and indeed most fungi have $\mathrm{pH}$ optima within the range of acidic $\mathrm{pH}$ ranging from 2.5 to 6.0 . Slightly acidic $\mathrm{pH}$ optima of the enzymes of the present investigation match the values characteristic for the fungal glycoside hydrolases (Christov et al. 1999).

$\alpha$-Galactosidases from various fugal sources exhibit acidic $\mathrm{pH}$ optima and several fungal $\alpha$-galactosidases are stable over a wide range of $\mathrm{pH}(\mathrm{pH} 3-12)$, which is a favorable property for biotechnological applications (Cao et al. 2009; Janika et al. 2010; Katrolia et al. 2012).

$\alpha$-Galactosidase produced from mesophilic and thermophilic fungi adapted to wide range of temperatures ranging from 50 to $65^{\circ} \mathrm{C}$ (Kotiguda et al. 2007; Simerska et al. 2007; Rezessy-Szabo et al. 2007; Viana et al. 2009).

Similar to our findings several researchers reported that thermostable $\alpha$-galactosidases are useful in food processing and other biotechnological applications, where operational conditions can denature thermo-labile enzymes (Brouns et al. 2006; Pessela et al. 2007).

Generally, metal ions have been shown to be relevant in enzyme activity. It has been reported that some metal ions such as $\mathrm{Ag}^{+}, \mathrm{Cr}^{+3}, \mathrm{Cu}^{+2}, \mathrm{Fe}^{+3}, \mathrm{Hg}^{+2}, \mathrm{Mn}^{+2}, \mathrm{~Pb}^{+2}$, and $\mathrm{Zn}^{+2}$ inhibited $\alpha$-galactosidase activity (Gote et al. 2006; Álvarez-Cao et al. 2018).

\section{Conclusions}

Based on our findings from the present study, we conclude that the locally available copra waste can be economically employed as substrate in SSF for the production of $\alpha$-galactosidase by Penicillium sp. Cheap and easily available media, which is very economical, was formulated. The fermentation medium containing $2 \%$ defatted copra meal was found to be the best medium along with yeast extract and ammonium nitrate for obtaining high enzyme titers by Penicillium sp. when compared to commercial mannans, viz., LBG, guar gum, etc. Optimization of culture parameters for obtaining maximal enzyme titers will lead to scale up of process for obtaining $\alpha$-galactosidase in large quantities for industrial use. The fungus Penicillium sp. does not produce toxins; their metabolic products enjoy generally recognized as safe (GRAS) status, and this can be used in the food industry. Further work for its complete application of $\alpha$-galactosidase and its application in food industry would be conducted with the aid of other biochemical techniques.

\section{Abbreviations}

sp.: Species; SSF: Solid state fermentation; CO: Finley grinded copra meal; FCO: Dried and sieved residues of copra meal; dFCO: Defatted copra meal; RFOs: Raffinose family oliogo-saccharides; GRAS: Generally regarded as safe; LBG: Locust bean gum; PDA: Potato dextrose agar; PNPG: p-Nitrophenyl a-Dgalactopyranoside

\section{Acknowledgements}

NVK thanks University Grant Commission (UGC).

\section{Authors' contributions}

NVK designed this research and performed the experiments. ACM, VT, and AGG guided and supervised the research work. NVK, ACM, and VT wrote the first draft and analyzed the result. AGG read the manuscript for correction. All authors read and approved the final manuscript.

\section{Funding}

UGC for financial support (UGC-MRP(S)-0372/13-14/KABA027/UGC-SWRO dated 28 March 2014).

\section{Availability of data and materials \\ Not applicable}

Ethics approval and consent to participate

Not applicable

\section{Consent for publication}

Not applicable

\section{Competing interests}

The authors declare that they have no competing interests.

\section{Author details}

${ }^{1}$ Department of Biochemistry, Maharani's Science College for Women, Palace Road, Bengaluru, Karnataka 560001, India. 'Department of Sericulture, Maharani's Science College for Women, Palace Road, Bengaluru, Karnataka 560001, India. ${ }^{3}$ Department of Microbiology, Maharani's Science College for Women, Palace Road, Bengaluru, Karnataka 560001, India. ${ }^{4}$ Department of Biochemistry, Gulbarga University, Kalburgi, Karnataka, India.

Received: 9 June 2020 Accepted: 8 September 2020

Published online: 23 September 2020

\section{References}

Álvarez-Cao ME, Rico-Díaz A, Cerdán ME, Becerra M, González-Siso MI (2018) Valuation of agro-industrial wastes as substrates for heterologous production of a-galactosidase. Microb Cell Factories 17:1-13

Álvarez-Cao ME, Cerdán ME, González-Siso MI, Becerra M (2019) Bioconversion of beet molasses to a-galactosidase and ethanol. Front Microbiol 10(405):1-15

Anisha GS. (2017) "a-Galactosidases," in current developments in biotechnology and bioengineering: production, isolation and purification of industrial products. eds A. Pandey, S. Negi, and C. Soccol (Amsterdam: Elsevier B.V. ), $369-394$.

Balabanova LA, Bakunina IY, Nedashkovskaya OI et al (2010) Molecular characterization and therapeutic potential of a marine bacterium Pseudoalteromonas sp. KMM 701 a-galactosidase. Mar Biotechnol (NY) 12 $111-120$

Bhatia S, Singh A, Batra N, Singh J (2019) Microbial production and biotechnological applications of a-galactosidase. Int J Biol Macromol 17(150): 1294-1313

Brouns SJ, Smits N, Wu H et al (2006) Identification of a novel a-galactosidase from the hyperthermophilicarchaeon Sulfolobuss olfataricus. J Bacteriol 88 2392-2399

Cao Y, Wang Y, Meng K et al (2009) A novel protease-resistant a-galactosidase with high hydrolytic activity from Gibberella sp. F75: gene cloning, expression, and enzymatic characterization. Appl Microbiol Biotechnol 83: 875-884

Chen M, Mustapha A (2012) Survival of freeze-dried microcapsules of agalactosidase producing probiotics in a soybar matrix. Food Microbiol 30:6873 
Christov LP, Szakacs G, Balakrishman H (1999) Production, partial characterization and use of fungal cellulase-free xylanases in pulp bleaching. Process Biochem 34:511-517

Clarke JH, Davidson K, Rixon JE et al (2000) A comparison of enzyme-aided bleaching of softwood paper pulp using combinations of xylanase, mannanase and a-galactosidase. Appl Microbiol Biotechnol 53:661-667

Dey PM, Pridham JB (1972) Biochemistry of a-galactosidase. Adv Enzymol 3:91130

Farzadi M, Khatami S, Mousavi M, Amirmozafari N (2011) Purification and characterization of a-galactosidase from Lactobacillus acidophilus. Afr J Biotechnol 10:1873-1879

Gomori G. (1946) Buffers in the range of pH 6.5 to 9.6. Proc Soc Exp Biol Med. May, 62, 33.

Gote MM, Khan MI, Gokhale DV et al (2006) Purification, characterization and substrate specificity of thermostable a-galactosidase from Bacillus stearo thermophilus (NCIM-5146). Process Biochem 41:1311-1317

Hossain MZ, Abe J, Hizukuri S (1996) Multiple forms of $\beta$-mannanase from Bacillus sp. KK01. Enzym Microb Technol 18:95-98

Janika S, Gernig A, Murray P et al (2010) Cloning and expression of a thermostable a-galactosidase from the thermophilic fungus Talaro mycesemersonii in the methylotrophic yeast Pichia pastoris. J Microbiol Biotechnol 20:1653-1663

Kang JJ, Desch KC, Kelly RJ, Shu L, ;Bodary PF, Shayman JA. (2019) aGalactosidase-A deficiency promotes von Willebrand factor secretion in models of Fabry disease. Kidney Int, 95,149-159

Katrolia P, Jia H, Yan Q et al (2012) Characterization of a proteaseresistant agalactosidase from the thermophilic fungus Rhizomucormiehei and its application in removal of raffinose family oligosaccharides. Bioresour Technol 110:578-586

Katrolia P, Rajashekhara E, Yan Q, Jiang Z (2014) Biotechnological potential of microbial a-galactosidases. Crit Rev Biotechnol 34(4):307-317

Kotiguda G, Kapnoor SS, Kulkarni D, Mulimani VH (2007) Degradation of raffinose oligosaccharides in soymilk by immobilized alpha-galactosidase of Aspergillus oryzae. J Microbiol Biotechnol 17:1430-1436

Lin TC, Chen C (2004) Enhanced mannanase production by submerged culture of Aspergillusniger NCH-189 using defatted copra based media. Process Biochem 39:1103-1109

Liu QP, Sulzenbacher G, Yuan H et al (2007) Bacterial glycosidases for the production of universal red blood cells. Nat Biotechnol 25:454-464

Naganagouda K, Mulimani VH (2006) Gelatin blends with alginate: gel fibers for a-galactosidase immobilization and its application in reduction of nondigestible oligosaccharides in soymilk. Process Biochem 41:1903-1907

Naganagouda K, Prashanth SJ, Shankar SK, Dhananjay SK, Mulimani VH (2007) Immobilization of Aspergillus oryzae a-galactosidase in gelatin and its application in removal of flatulence-inducing sugars in soymilk. WJ Microbiol Biotechnol 23:1131-1137

Naganagouda K, Salimath PV, Mulimani VH (2009) Purification and characterization of endo-beta-1,4mannanase from Aspergillus niger gulbarga for application in food processing industry. J Microbiol Biotechnol 19(10): $1184-1190$

Pessela BCC, Fernandez-Lafuente R, Torres R et al (2007) Production of a thermo resistant a-galactosidase from Thermus sp. strain $\mathrm{T} 2$ for food processing. Food Biotechnol 21:91-103

Raja P, Parthiban M, Ghadevaru S (2020) Isolation, molecular characterization, purification and production optimization of alpha galactosidase enzyme from Bacillus subtilis. Vet Res Int 08(02):88-93

Rezessy-Szabo JM, Nguyen QD, Hoschke A et al (2007) A novel thermostable agalactosidase from the thermophilic fungus Thermomyces lanuginosus CBS 395.62/b: purification and characterization. Biochim Biophys Acta 1770:55-62

Scalabrini P, Rossi M, Spettoli P, Matteuzzi D (1998) Characterization of bifidobacterium strains for use in soymilk fermentation. Int J Food Microbiol 39:213-219

Shankar SK, Mulimani VH (2007) -Galactosidase production by Aspergillus oryzae in solid-state fermentation. Bioresour Technol 98(4):958-961

Shibuya H, Kobayashi H, Sato T et al (1997) Purification, characterization and cDNA cloning of a novel a-galactosidase from Mortierella vinacea. Biosci Biotechnol Biochem 61:592-598

Simerska P, Monti D, Cechova I et al (2007) Induction and characterization of an unusual a-D-galactosidase from Talaromyces flavus. J Biotechnol 128:61-71
Viana PA, de Rezende ST, Passos FML et al (2009) Debaryomyces hansenii UFV-1 intracellular a-galactosidase characterization and comparative studies with the extracellular enzyme. J Agric Food Chem 57:2515-2522

Youssef AS, Moustafa Y, Naggar EL, Assar SA, Beltagy EA (2006) Optimization of cultural conditions for $\beta$-mannanase production by a local Aspergillusniger isolate. Int J Agric Biol 8(4):539-545

\section{Publisher's Note}

Springer Nature remains neutral with regard to jurisdictional claims in published maps and institutional affiliations.

\section{Submit your manuscript to a SpringerOpen ${ }^{\circ}$ journal and benefit from:}

- Convenient online submission

- Rigorous peer review

- Open access: articles freely available online

- High visibility within the field

- Retaining the copyright to your article

Submit your next manuscript at $>$ springeropen.com 